\title{
Economic Contribution of Homestay Tourism: A Case Study of Magar Homestay of Naruwal, Lamjung
}

\author{
Dambar Ale Magar \\ Marsyangdi Multiple Campus, Lamjung
}

\begin{abstract}
Tourism involving homestay is one of the Nepal government's key efforts to diversify its cultural tourism product. Moreover, homestay can be a new model of tourism development in Nepal. This article aims to highlight the economic contribution of homestay entities based on the descriptive design. Data were collected from the ten homestay entities of Magar homestay at Naruwal, Lamjung through in-depth interviews. The contribution of homestays has been studied from various aspects like average income earned, the number of jobs created, women entrepreneurs, reverse migration, development of infrastructure, rise in living standard, etc. The result shows that the rate of income and expenditure has been gradually increased since the date of homestay tourism commencement in the community. This study has found that many of the respondents have managed their daily expenditures through the income of homestay entities. All homestay operators have reported the increment in their economic status. However, it is also found that there is a need to improve the quality of service to increase the flow of national and international visitors/tourists.
\end{abstract}

Keywords: homestay, socio-economic development, homestay operators, village tourism, employment generation

\section{INTRODUCTION}

Nepal is a developing country, mostly with diverse geographic conditions. More than the cities, a vast majority of people reside in rural and remote areas. In this respect, the living standard of a rural area is to be raised with great importance. Similarly, Nepal consists of many natural, cultural, historical, and adventurous products. These products are the main attractions for visitors throughout the world. Nepal is rich not only in natural resources but also in tradition, religion, and culture. The habit of travelling has originated the growth of the tourism industry. The nature of travelling activities may vary from the early period to the date. Over time, the meaning of travelling has been shifted from the necessity to the desire of taking splendid journeys. (Ranjit, 1976, p.17)All in all, tourism plays a vital role in the economic and socio-cultural development of Nepal. Homestay concept is particularly found in rural areas that include both cultural and natural sites. These kinds of initiatives lure visitors/tourists to experience and witness the culture of the offbeat sites and also to inject money directly into the economy of these areas.

The concept of homestay has received the attention of public and private stakeholders due to the clear opportunities it presents in the economic development of the area. The homestay programmes have been considered as a tool that helps in the development of the community 
(Acharya \& Halpenny, 2013). Homestays are also considered as small-scale enterprises and the hosts as micro-hospitality entrepreneurs. It generates income in small amounts and contributes to economic prosperity and community development in the area. Local communities generate income directly and indirectly through homestay programme which also empowers them by providing local employment, poverty alleviation, attracting tourists, and enriching the experience of tourists by showcasing the natural and cultural heritage of the destination. (Agyeiwaah, 2013) Nepal is a small landlocked country with geo-diversity ranging from plain region to the highest peak in the world. Similarly, it also has diverse vegetation. Nepalese practice different religions and cultures. Nepal includes different world cultural heritage sites like Lumbini, Pashupatinath, Swoyambhunath, and so on. Hence, having all these qualities, Nepal is one of the best tourist destinations in the world.

\section{Homestay: Concept in Nepal}

The concept of community-based tourism was first coined in the year 1970s in the world (Mitchell \& Muckosy, 2008). Community-based tourism is the outcome of Rio-De-Jenerio, Brazil, Summit in 1992 for its sustainable development.

Nepal Government first introduced the homestay concept in 2007 AD though it was the old concept in the world that has a significant role in the development of rural sector life-style in Nepal (Devkota, 2010). This programme was floated to provide additional accommodation for the anticipated number of tourists visiting the country during Nepal Tourism Year 2011. The government wanted to promote fairs and festivals, dance, music, food, and the lifestyle of the local people. Similarly, the prime aim of homestay is to enhance rural people's participation in the tourism sector. Two modalities have been planned as 'Community homestay' and 'Private home stay'. It is also believed that such homestay programmes in rural areas will provide additional income for the locals. In urban areas, privately owned homestays are also encouraged to allocate two rooms with two beds each. Under the homestay idea, anybody who has a home with at least four rooms can use the empty rooms for tourist' homestay. At the same time, the host should be able to provide organic food with local culture and tradition. Nepal government has set the provisions or rules for the homestay operators. Firstly, they have to register their houses who would like to provide homestay accommodation at the local Homestay Management Committee. Secondly, the house owner must be able to provide hygienic food with local taste and good room facilities. The accommodation package and other charges are determined by the Local Homestay Management Committee.

The homestay management committee further sets the rules for the homestay operators where hosts should be able to ensure cleanliness and a safe and secure environment, adequate toilet and bathroom facilities. The numbers of guests are determined as per the space available in a house. As per the guideline put forward by the concerned authorities, tourists are to be served the same food that the house owners consume. The guideline includes a code of conduct for tourists as well. Visitors have to dress appropriately and accept the hosts' culture and traditions. Further, they are advised not to use any drugs and narcotics. People's concept about tourism has 
been changed with the development of rural tourism around the globe. Tourists prefer different activities like walking, climbing, horse riding, adventure, fishing, hunting, seeing culture, heritage, temples besides luxurious hotels and resorts. (Kunwar, 1997)

Rural tourism contains differentiation, uniqueness, specialty, and peculiarity than luxurious tourism. It gives tourists to experience far away from busy, hectic, and crowded infrastructural urban areas to the peaceful calm locality full of splendid natural surroundings, by offering them to stay in natural, clean, comfortable, and pocket-friendly accommodation and authentic local foods. This article mainly attempts to further boost and help homestay operators to effectively run their business. Similarly, it aims to understand the perception of the local community towards the homestay programme in Naruwal, Lamjung and, to review and analyze the economic impacts of the homestay programme on the local community. It explored how the people of the study area improved their economic status through homestay tourism.

\section{LITERATURE REVIEW}

Club Mediterranean at first introduced the concept of rural tourism to provide different environments and locations to the people living in the city in 1950 named as 'Vocation Village', in Majorca, a Spanish Island. Rural tourism is demand-centric, the desire of tourists to see 'other' culture and lifestyle which is often considered as primitive and unique from their own (Kunwar, 1997).

\section{Defining Homesay}

Although homestay is considered a relatively new concept, it is an age-old concept where travelers used to stay with a family as a guest and there was no concept of a commercial accommodation system. The word homestay is composed up of home and stay which refers to staying or loading in somebody's home as a guest by paying some monitory value on a rent basis for some specific tenure (Azwar, 2020). This term might be different in different countries. For example, homestay is regarded as farmhouse accommodation in Australia whereas in the United Kingdom it is often associated with learning the English Language. The concept of homestay is comparatively new (Klepinger, 1995), as it currently has other meanings apart from the original definition which defines the homestay as a place for international students requiring accommodation. The Merriam Dictionary (Merriam Webster Corporation, 2002) defines it as "a period during which a visitor in a foreign country lives with a local family". A guest at one's home for a short period with the cost is a home-stay tourist and the service related to such tourist is called homestay tourism. But such guests are provided accommodation and services by individual families as well as the community too (Timalsina, 2012). Since the people living in rural areas follow the practices of traditional living in a better way, homestays become an ideal way for the tourist to get in touch with local customs and culture. Such practices have created cultural exchange by sharing life and family experiences.

The Malaysian definition of homestay has been adopted for this study. In the Malaysian homestay context, it is an experience where visitors stay with selected families, interact and 
experience the daily life of host families, and experience Malaysian culture as well. Normally, the guest house is located in a village surrounded by hills or paddy fields. Guests are allowed to join the locals to go fishing, prepare dinner or simply enjoy an idyllic village lifestyle (Ibrahim \& Razzaq, 2010).

The homestay concept is new to all. Hence, it should be registered to the Tourism Board of the nation and a local management committee is formed to run the programme in the community effectively. There are several stakeholders in the homestay industry namely homestay providers, homestay hosts, and homestay guests. A homestay provider is the coordinator of the homestay programme whose responsibility is to organize quality accommodation (Corina, 2018). Similarly, homestay host refers to the families who offer their homes to the guests for the whole duration of their stay. And the homestay guests refer to the people who occupy the hosts' houses for a fee. It is the door to find possibilities, to understand a new and untapped place resulting in the government enable to promote widely as a new tourist destination and arrange for an alternative source of income to the rural host population (Gangotia, 2013). In homestay tourism, visitors get ample chance to spend quality time with the local family observing their customs, values, and culture, which is an excellent opportunity to realize the taste of rural life and tradition. The environment along with culture is inseparable in the tourism business. The market value of this homestay business has been grown up with the demand of visitors. This business offers financial rewards and monetary help to the local native community for restoring, protecting, and conserving the environment and their indigenous culture. Market value is created with the demand of visitors where both environment and culture are commoditized (Laurie \& Radcliffe, 2005). We can say that tourism is a component that is concerned with development, giving importance to discover the ways of expanding constructive impacts. Homestay tourism is an effective tool to minimize rural poverty and reverse migration. It assimilates many types of activities like trekking, cultural tourism, agro-tourism, health tourism, and eco-tourism. It helps to increase tax revenue in a particular country. It may also stimulate new markets for the local community to showcase and trade their products, for example, agricultural products, crafts, and others. The literacy rate in the community remains increasing gradually through this programme. The homestay concept has also been discussed in several other ways and that has led to homestays being known as various other names as cultural homestays, heritage homestay, educational homestay, leisure stay, culture stay, volunteer stay, and urban stay (Pasa, 2020).

\section{Village Tourism}

Village tourism is community-based tourism that is considered a new concept in tourism studies. It involves the participation of local people in the development of tourism in their area. The studies on this concept started around 1990. The importance of community-based tourism has also been highlighted by the Third World Countries in their development agenda. It is considered very important for the local people as it empowers them and supports them by increasing the rate of development (Corina, 2018). 
Before $1951 \mathrm{AD}$, tourism activities were limited to major trekking routes, the mountains, and adventure tourism in Nepal. The concept of village tourism was introduced to increase and maximize economic benefits and to generate job opportunities for the local people who depend only on agriculture. Nepal government started providing basic infrastructures like roads, electricity, and telecommunication (Lama, 2013). A village tourism programme was included in the national tourism policy in 1995 in Nepal. Nepal Village Resorts (NVR), a Kathmandu-based travel agency started to work as a marketing agency of the village tourism products, launched village tourism for the first time in Nepal in Sirubari Village in 1997 AD. The local people were actively engaged in the planning stages of Sirubari Village Tourism (Thakur, 2013). Since then other villages also started the village tourism programme taking the example of the Sirubari programme, but it suffered a major setback afterward, due to the outbreak of Maoist insurgency in Nepal (1995AD). After the Peace Agreement between the Nepal Government and Maoist Party in 2005AD, a certain level of political stability helped to boost village tourism in different parts of the country. For the effective development and growth of rural tourism in Nepal, each village possesses its own Tourism Development Management Committee that consists of community members (Shrestha, 2015).The committee is responsible for assigning guests to hosts, which is done on a strictly rational basis. The committee also checks the quality of cleanliness ensures accommodation standards and organizes different cultural activities, events, and educational programmes for the growth and promotion of village tourism in the local community.

\section{METHODOLOGY}

To achieve the set objectives, a qualitative research approach was chosen (Caldas, 2009). I used a case study research design to explore people's economic activities in the study area. The total population of the study was 10 homestay owners and 3 members of the Homestay Management Committee (HMC). The study population was selected using a purposive sampling procedure (Caldas, 2009). I interviewed 10 homestays owners and 3 members of the HMC. I conducted in-depth interviews to explore the socio-economic activities of the homestay. The interview guidelines included the socio-cultural and economic impact of homestays, benefits and challenges of running homestays in rural areas, the contribution of homestays in generating economic activities and empowerment, and possibilities of further expansion of homestays in the study area. Similarly, I observed their activities as a participant-observer.

I used primary and secondary sources of data to analyse this study. For example, the data from the study population and my observation were the primary sources of data collection. Similarly, I employed various newspapers, magazines, reports, research papers and theses related to homestays tourism at home and abroad as secondary sources of data. The recorded interviews were transcribed, codified and developed various themes according to the research objectives (Banks, 2009). 
The Snowball sampling method was used to choose the respondents for the study. Snowball is also known as chain referral sampling. This is a purposive sampling method that considers several factors like the kind of resources available for the study, availability of time, the objectives of the research, and data saturation. Data saturation is a point where the additional data cannot bring additional insights to the research (Banks, 2009).

\section{FINDINGS AND DISCUSSION}

This section deals with a brief introduction of the study area and various themes based on the interviews and observation.

\section{Study Area}

The study area was a Magar homestay village of Besishahar 2, Lamjung, Nepal. The study is $6 \mathrm{~km}$ away from Besishahar, the district headquarter of Lamjung. It is accessible in half an hour on foot from Gairi, on the way of Besishahar-Dumre highway. The homestays were run by the Magar community, a major ethnic community of Nepal. Roughly, the total population of the Magar was 400. The village is famous for the sight scene of the eye-catching snow-covered mountains including Manaslu, Himchuli, Harka Peak, BouddhaHimal, LamjungHimal, Annapurna I and III and Gangapurna in the Annapurna range. Considering the natural beauty of the village, the typical Magar culture, availability of organic food and good hospitality of the local people, a group of intellectual people put forward the concept of homestay tourism since 2009AD and, finally, the Magar Homestay was inaugurated in 2018AD by the Honorable Chief Minister PrithviSubbaGurung (Gandaki Province) in the presence of the Army Chief of Nepal General Purna Chandra Thapa. A 15 member homestay management committee has been formed. Now, 10 homestays are in use. With the objectives to empower the women of the Magar community, their skill development, economic development, and the preservation of language and culture, the concept of homestay tourism was developed in the village, and now the local people believe that it has been able to convey a positive message about the village and the Magar culture.

\section{Economic Contribution of Homestay}

The participants involved in the study reported that homestay tourism has created an opportunity to improve their economic status. They explained that homestay tourism has promoted the local products, created job opportunities for the local people, developed women entrepreneurs, improved the living standard of the people, supported to reduce poverty, and developed various infrastructures in the village. For example:

Before we started homestays, the local products did not get more value. We used to consume them for our family purpose. We had a survival farming system. Now, we have started to produce various products including vegetables, domestic animals and organic foods focusing on the demand of 
the guests in homestays. The local products have got market (Bir Singh Rana, HMC member).

These comments reflected that homestay has provided the opportunity for marketing other local products. It has created the opportunity for self-employment. Income from homestay tourism was enough to manage the basic expenditures. Undoubtedly, quality service can add the number of tourists in rural tourism. Therefore, there was a need to monitor the compliance of basic standards of homestay developed by the Nepal Government. This is supported by the study of Neupane (2017) who investigated that despite the cultural preservation, the rural homestays of Nepal have created more opportunities for their economic empowerment by utilising domestic products.

Similarly, all the participants reported that homestay tourism has created job opportunities for local people. For example, the owner of homestay no. 1 said:

Local people are involved in various jobs such as nature guides, housekeepers, cooks, drivers, and wage-based workers. Due to the Covid-19 pandemic, the flow of visitors has declined this year. We are preparing our infrastructures during these periods and many people are working as wage workers for homestay construction.

These remarks reflected how homestays have contributed to generating jobs for local people and use their skills in the productive field. The involvement of people in various jobs can improve their economic status and living status. This is in line with the study carried out by Acharya and Halpenny (2013) which examined how homestays contributed to sustainable development by generating job opportunities and promoting local and organic products in the home and abroad.

\section{Women Entrepreneurs}

The majority of the respondents involved in the interview from the local community were female. I tried to explore the ways they benefited through it. It was found that more females were motivated in the homestay programme in comparison to the men in the family. They were involved in activities like cooking, planning, managing, interacting with guests, cleaning, etc. Female ownership in the very business was helping in regular income generation for women and involved them in mainstream development by encouraging gender equality. Even handmade souvenirs to tourists were other jobs created by the homestay programme. For example, Bi Maya Ale said:

I am a ward community member. I actively participate in the decision-making process at the local level. Women have managed homestays very well and generate more resources of income. I along with other women conduct various training like tailoring, knitting, cooking, and so on resulting in women's empowerment in the village. 
Homestays have developed women entrepreneurs for community development activities and make women major stakeholders for homestay development.

\section{The Rise of Living Standard}

The study homestays were found to contribute to the promotion of local resources. It has provided an alternative way of self-employment for generating income to subsidize the expenditure. This is supported by Thakuri (2016) who argued that homestay programmes have increased the living standard of the community people. It has flourished the facilities like hygienic conditions, schools, recreation grounds, library, museum, etc. GOs, NGOs, and local bodies have been supporting the programme. The study found a satisfactory level of income from homestay resulting in a rise in living standards.

\section{Development of Infrastructure}

Magar homestays of the study area were found equipped with basic infrastructure facilities like roads, drinking water, sewage and drainage, public toilets, electricity, communication, etc. Since the announcement of the three-layered government in Nepal. The local government,i.e. Besishahar Municipality has also been taking special care of the infrastructural facilities throughout the municipality.

\section{Economic Sustainability}

Homestay programmes have made an alternative source of income to rural entrepreneurs. The participants explained that tourism has employed other members of the family apart from the headman. Above all, such activities supported the family economically. Homestay tourism may create a risk of shifting the traditional economy to a market-based economy. This is in line with Budhathoki (2013) who mentioned that the living cost of local people may increase in demand for foreign goods and technology. It provides only seasonal employment.

\section{Reduction in Poverty and Control Migration}

The homestay programme is a major scheme that helps in the reduction of poverty in an area. The result indicated that income generated through various tourism activities may result in a reduction in the poverty level in the village. Also, the youth who had migrated to other cities in search of jobs have started to return because there are ample employment and entrepreneurial opportunities available. For example, Ram BahadurRanaMagar, an HMC member shared his experience that he left his foreign employment and was involved in homestay tourism. He reported that the migration rate has declined after they started homestay tourism.

\section{Improve Literacy Rate}

The participants involved in the study reported that homestay tourism has developed educational awareness among the local people. Besides general education, I observed local people using computers and social media. They used the new technology to spread awareness 
about their products and services. However, the local community people should be aware of ecofriendly practices and responsible for the same.

\section{Promote Local Cultures}

I observed that local people have preserved local cultures because the guests wanted to enjoy with local culture in local taste. The participants expressed that local people got an opportunity to have interaction with people from various cultures and ethnicity. This helped in the survival of traditions and culture. I observed people presenting Magar cultural dances like Chudka, Kaurah, Sorathi, Maruni, etc. were presented to the guests.

\section{Capacity Building Practices}

The participants reported that local people were getting engaged besides homestay programmes like animal husbandry, bee-keeping, farming, handloom cottage, etc. The research indicated that homestay tourism is an experience-based phenomenon that is directly linked with the lifestyle of the local people and is also geared towards protecting the local culture, heritage, and traditions.

\section{CONCLUSION AND IMPLICATIONS}

Tourism is a multidimensional product that can be flourished only after the development of infrastructures like transportation, communication, drinking water, hospital, school, etc. It has increased awareness among local people to preserve their natural resources and social culture and customs as well. It is observed that Magar homestay at Naruwal has a positive impact. The more the participation of local people and enhanced marketing of tourism may help to grow tourist flow in village and people will be more benefited. While developing infrastructures to attract tourists, the local environment is adversely affected. Therefore, protecting the environment, providing good service, preserving local tradition and culture should be the main goal of the government and the community to make it the best.

This study offers some important implications for the success of the homestay programme in other parts of Nepal. All in all, it contributes firstly, to the theoretical literature on homestay tourism from the perspectives of the local people. Similarly, the current study contributes to the research by exploring various criteria on which economic benefits can be explored. Moreover, the study also has practical implications for the policymakers and the practitioners as they can utilize the study for destination planning and development. This study presents some limitations which provide the opportunity for future researchers. This article has limited the analysis to one particular area of Lamjung district indicating the generalized issues. Future researchers can include more villages and also a comparative analysis can be made.

After the analysis of all interviews, the outcome indicated that the locals were very pleased by homestay tourism. At present, the homestays are receiving only internal visitors/guests. The number of visitors was higher last year but the pandemic of the COVID-19 has been adversely affecting the business now. Based on my observation of the homestays, I have 
recommended some suggestions for the better improvement of the homestays. Mass tourism has always had negative impacts on the environment as they weaken the quality of the local environment and region. So far so good, the tourism industry can't be regarded as one hundred percent sustainable, the visitors, the service providers, and the tourist agents and counselors have to understand sustainable tourism and lead tourism growth according to the rule of sustainability. Similarly, the hosts always should keep in mind that preserving the local and cultural tradition and heritage, conserving natural resources and beauties and promoting the country as an ideal tourism destination country can benefit a lot economically. Likewise, unplanned urban development has forced rapid and uncontrolled flops like irregular, substandard, and inaccessible housing development such as loss of open space and decreased livability. Hence, policymakers should focus on how to categorize homestay tourism. Increased importance for the religious and cultural festivals and events can enhance the development of museums but at the same time, it has few negative effects on the local traditions and culture. For instance, Nepal has 123 different spoken languages all over the country but in the present context, the vocabularies of some languages are missing and some languages are not spoken at all. Therefore, Magar homestay operators should also emphasize the mother tongue. Since people launched the concept of community homestays, all the owners should develop good relations with each other for the promotion of homestays. Furthermore, the lodge used by previous visitors should be thoroughly cleaned once they leave the home. Homestay operators are suggested to focus on organic foods so that the agro-based food production will increase.

\section{REFERENCES}

Acharya, B.P. \& Halpenny, E. A. (2013). Homestays as an alternative tourism product for sustainable community development: A case study of women-managed tourism product in rural Nepal. Tourism planning and development. 10 (4), 367-387. https://doi.org/10.1080/21568316.2013.779313

Agyeiwaah, E. (2013). International tourists' motivations for choosing a homestay in the Kumasi Metropolis of Ghana. Anatolia, 24, pp.405-409. https://doi.org/10.1080/13032917.2013.789972

Asker. S, Boronyak, I., Carrard.N., \& Paddon, M. (2010). Effective community based tourism. In APEC Tourism Working Group.

Azwar, H., Yudistira, S., \& Edmizal, E. (2020). Improving local community knowledge and skills in homestay management. In 1st Progress in Social Science, Humanities and Education Research Symposium (PSSHERS 2019) (pp. 6-9). Atlantis Press. Banks, K.H. (2009). A qualitative investigation of white students' perceptions of diversity. Journal of Diversity in Higher Education. https://doi.org/10.1037/a0016292

Berger, V. (1978). The economic impact of tourism in Nepal: An Input-Output Analysis. Cornel University

Budhathoki, B. (2013). Impact of homestay tourism on livelihood: A case study of Ghale Gaun, Lamjung, Nepal. Norwegian University of Life Sciences.

Caldas, M.P. (2009). Research design: Qualitative, quantitative, and mixed methods approach. 
Revistade Administracao Contemporanea. https://doi.org/10.1590/s141565552003000100015

Corina, S. G. (2018). Rural tourism an opportunity for sustainable development. Ovidius University Annals, Economic Sciences Series, 18(2), 349-353.

Gangotia, A. (2013).Tourism homestay scheme in Himanchal Pradesh: A successful story of community-based tourism initiatives (CBTIS) STHM. (2277). pp 206-207

Ibrahim, Y., \& Razzaq, A. R. A. (2010). Homestay programme and rural community development in Malaysia. Journal of Ritsumeikan Social Sciences and Humanities, 2(1), $7-24$.

Klepinger, L. (1995). The Australian/Japanese homestay programme and its positive contribution to cross-Cultural understanding. Retrieved from http://itesli.org/Articles/KlepingerHomestay. html (August 2010)

Kunwar, R. R. (1997). Tourism and development. Science and Industry Interface.Kathmandu Lama, M. (2013). Community homestay programmes as a form of sustainable tourism development in Nepal.

Laurie,N.D., \& Radcliffe, S.A. (2005).Working the spaces of neoliberalism: Activism, professionalization and incorporation. In N.D.Laurie,\& L.Bondi, Ethnodevelopment: Social Movements, Creating Experts and Professionalising Indigenous Knowledge in Ecuador.

Merriam Webster Corporation. (2002). Merriam Webster Dictionary. Ministry of Culture, Tourism and Civil Aviation, Homestay working Procedure 2067 viewed on 10th August 2015, http://www

Mitchell, J. \& Muckosy, P. (2008). A misguided quest: Community based tourism in Latin America. Opinion. London. ODJ. Overseas Development Institute

Neupane, B. (2017). Role of homestays in economic empowerment in Nepal. A Concept Paper Submitted in Rural Homestay Conference (14 January, 2017).

Pandey, R.N., Chhetri, P.\& Kunwar, R.R. (1995). Case study on the effects of tourism of tourism on culture and the environment.[Online] Available at:

http://unesdoc.unesco.org/images/0012/001226/122619oe.pdf [Accessed 05 March 2016]

Pasa, R. B. (2020). Tourism in Nepal: The models for assessing performance of Amaltari Bufferzone Community Homestay in Nawalpur. Nepalese Journal of Development and Rural Studies, 17, 54-71.

PRASAIN, S., (2015). Homestay boosts incomes, inviting standards in Bardia.

Shrestha, D. (2015). Nepal rural tourism. Welcome to Nepal rural tourism [online] Available at:http://www.nepalruraltourism.com/[Accessed 06 March 2016]

Thakuri, I. B. M. (2016). Economic contribution of homestay in Nepal, Journal of Advanced Academic Research (JAAR)

Thakur, M. R. K. (2013). Community-based village tourism in Nepal: A case study of Sirubari village, Nepal (Doctoral dissertation). The Global Open University.

Timalsina, P. (2012). Homestay tourism boosts GhaleGaon's economy. Retrived 5 7, 2015, fromhttp://www.gorkhapatra.org.np./rising.detail.php?Article id=23200\&cat id=4 